\title{
Use of point-of-sale data to assess food and nutrient quality in remote stores
}

\author{
Julie Brimblecombe ${ }^{1, *}, \boldsymbol{t}$, Robyn Liddle ${ }^{1}$ and Kerin $\mathrm{O}^{\prime} \mathrm{Dea}^{2}$ \\ ${ }^{1}$ Menzies School of Health Research, Charles Darwin University, Darwin, NT, Australia: ${ }^{2}$ Sansom Institute for \\ Health Research, University of South Australia, Adelaide, SA, Australia
}

Submitted 2 August 2011: Final revision received 7 July 2012: Accepted 26 July 2012: First published online 25 September 2012

\begin{abstract}
Objective: To examine the feasibility of using point-of-sale data to assess dietary quality of food sales in remote stores.

Design: A multi-site cross-sectional assessment of food and nutrient composition of food sales. Point-of-sale data were linked to Australian Food and Nutrient Data and compared across study sites and with nutrient requirements.

Setting: Remote Aboriginal Australia.

Subject: Six stores.

Results: Point-of-sale data were readily available and provided a low-cost, efficient and objective assessment of food and nutrient sales. Similar patterns in macronutrient distribution, food expenditure and key food sources of nutrients were observed across stores. In all stores, beverages, cereal and cereal products, and meat and meat products comprised approximately half of food sales (range 49-57\%). Fruit and vegetable sales comprised 10.4 (SD 1.9) \% on average. Carbohydrate contributed $54 \cdot 4$ (SD 3.0) \% to energy; protein 13.5 (SD 1.1) \%; total sugars 28.9 (SD 4.3$) \%$; and the contribution of total saturated fat to energy ranged from $11 \cdot 0$ to $14 \cdot 4 \%$ across stores. $\mathrm{Mg}, \mathrm{Ca}, \mathrm{K}$ and fibre were limiting nutrients, and $\mathrm{Na}$ was four to five times higher than the midpoint of the average intake range. Relatively few foods were major sources of nutrients.

Conclusions: Point-of-sale data enabled an assessment of dietary quality within stores and across stores with no burden on communities and at no cost, other than time required for analysis and reporting. Similar food spending patterns and nutrient profiles were observed across the six stores. This suggests potential in using point-of-sale data to monitor and evaluate dietary quality in remote Australian communities.
\end{abstract}

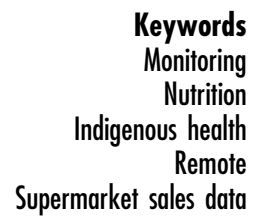

Dietary improvement for Indigenous Australians is a priority strategy for reducing the health gap between Indigenous and non-Indigenous Australians. Overweight and obesity $(11 \cdot 4 \%)$ is the second highest contributor after tobacco use $(12 \cdot 1 \%)$ to the extremely high disease burden experienced by Indigenous Australians ${ }^{(1)}$. Its contribution increases sharply from a relatively young age, driving the very high incidence of type 2 diabetes, CVD and related conditions such as kidney failure at ever younger ages. The $26 \%$ of Indigenous Australians who live in remote areas experience a disproportionate disease burden $-40 \%$ of the excess preventable illness ${ }^{(1)}$.

Much of this burden of disease is due to extremely poor nutrition across the life course. Measuring food consumption is necessary to monitor progress towards

$\dagger$ Address for correspondence: Menzies School of Health Research, John Mathews Building (58), Royal Darwin Hospital, PO Box 41096, Casuarina, NT 0811, Australia. national dietary goals and to identify areas for improvement. However, dietary data for Indigenous Australians have not been routinely available from national nutrition surveys or any other source, with a consequent gap in information on a major determinant of health.

In remote communities, the store provides much or most of the food supply ${ }^{(2,3)}$. There are about 175 stores in remote Australia ${ }^{(3)}$. Two decades previously, the store in remote communities was shown to provide an estimate of 'community dietary quality profile ${ }^{\text {(4) }}$ and has been used to monitor the health impact of interventions to improve diet quality ${ }^{(5,6)}$. Likewise, in urban settings overseas, supermarket sales data have been shown to be a valid source of information on household food and nutrient availability where supermarket foods are the largest single contributor to $\operatorname{diet}^{(7)}$.

The aim of the present study was to examine the feasibility of assessing dietary quality of food sales in remote stores using point-of-sale data. To do this we examined 
differences and consistencies in point-of-sale data across six community stores in relation to: (i) food expenditure patterns; (ii) nutrient profiles (macronutrient contribution to energy and nutrient density - nutrient per $1000 \mathrm{~kJ}$ ); and (iii) major food sources of macro- and micronutrients.

The study was conducted under the Remote Indigenous Stores and Takeaway (RIST) project. All community stores consented to provide data for the purposes of the RIST project.

\section{Methods}

\section{Setting}

Six stores in remote Aboriginal Australia from three states and the Northern Territory, ranging in size from 185 to 880 residents of mostly Aboriginal ethnicity with comparable age and sex distributions (Australian Bureau of Statistics census data) $^{(8)}$ (Table 1), participated in the present study. The stores represented a cross-section of communities in different regions of remote Australia, of different sizes and store ownership structure. The distance between study stores was vast: study communities were located $300 \mathrm{~km}$ to nearly $3000 \mathrm{~km}$ in distance from Darwin (the capital of the Northern Territory). Distance from each community to the nearest food wholesaler ranged from $210 \mathrm{~km}$ to over $1000 \mathrm{~km}$. Alcohol was not available in any stores and prohibited in five of the six communities.

\section{Data collection}

Electronic point-of-sale data were provided at no cost by each store for a 3-month period (July-September) in 2006 when road closure due to seasonal conditions would be minimal. A 3-month period was used to ensure adequate capture of products including those with slow stock turnover $^{(4)}$.

All food and beverage items, with the accompanying Universal Product Code (barcode) or store-derived product code, quantity sold and dollar value (retail price), were imported into a purposely designed Access database (Microsoft ${ }^{\circledR}$ Office 2003). Unit weights were derived for all food and drink items ${ }^{(9)}$. Volume (millilitres) was converted to weight (grams) using a specific gravity conversion factor $^{(10)}$. Each food and drink item was assigned a food group according to the Australian Food and Nutrient food grouping system ${ }^{(10)}$.

Food and beverage weights were expressed per edible fraction and their energy and nutrient contents sourced from the Australian Food and Nutrient reference and survey databases (NUTTAB 20006, AUSNUT 2007 and AUSNUT 1999) ${ }^{(10)}$. Where possible, brand-specific nutrient composition was sourced. Nutrition Information Panels and recipe development were used to derive the nutrient composition of ten food types (twenty-three food lines) not available in the food and nutrient databases. Matching of the 5569 food lines (1151 nutritionally unique items) with nutrient data was performed by two nutritionists with an agreement rate of $94 \%$. Average nutrient quantities per $100 \mathrm{~g}$ were multiplied by the edible weight of each of the food and beverage items sold ${ }^{(11)}$ and for each food group.

\section{Analysis}

Percentage contribution of protein, total fat, saturated fat, carbohydrate and total sugar to energy content of food sales was determined for each store and for stores combined. Nutrient density (nutrient availability per $1000 \mathrm{~kJ}$ ), which is independent of population size, was used to assess the dietary quality of food sales and for community comparisons $^{(12)}$. Nutrient densities were compared with population-weighted nutrient density requirements derived from Australian nutrient reference values (Recommended Dietary Intakes (RDI) and Estimated Average Requirements $(\mathrm{EAR}))^{(13)}$ and national census data for each community ${ }^{(8)}$. The RDI is the average daily dietary intake level sufficient to meet the nutrient requirements of nearly all (97-98\%) healthy individuals in a particular life stage and gender group. The EAR is a daily nutrient level estimated to meet the requirements of half the healthy individuals in a particular life stage and gender group ${ }^{(13)}$. Adequate Intake (AI) values were used for those nutrients where EAR and/or RDI were not available ( $\mathrm{K}$, dietary fibre, protein and vitamin $\mathrm{E}$ $\alpha$-tocopherol equivalents). The midpoint of the AI range was used for $\mathrm{Na}$.

Foods contributing $10 \%$ or more of a specific nutrient were considered a major food source ${ }^{(14)}$.

\section{Results}

In all communities, the store provided nearly $40 \%$ or more of the estimated population energy requirement (range 39-153\%) according to 2006 census data (Table 1). Lower percentages were shown for Stores 2 and 4 where competing food outlets existed in the community. A lower population at the time of the study than that stated in the 2006 census for Community 6 (personal communication, community informant) explained the exaggerated percentage for population energy requirement.

In five out of six stores, beverages comprised the highest percentage of dollar sales, 21.4 (SD 1.4) \%, compared with $10 \cdot 4$ (SD 1.9) \% for fruit and vegetables (Table 2 ). The macronutrient profile was similar in all stores and showed a similar pattern to that reported by Lee et al. in the late 1980s for six remote stores in the Northern Territory using store invoice data ${ }^{(12)}$ (Table 3). On average carbohydrate comprised more than half of the energy from food sales and percentage to energy for protein was lower than the recommended minimal intake. Percentage fat to energy $(31 \cdot 8(\mathrm{SD} 3 \cdot 2) \%)$ was at the high end of the recommended range and similar to that reported in 1986/1987 for remote Northern Territory community 
stores $^{(12)}$ and for wider Australia from self-reported dietary intake data ${ }^{(15,16)}$ (Table 3).

For all stores combined, nutrient densities, when compared with the population-adjusted nutrient densities (using $\mathrm{EAR}$ ) or $\mathrm{AI}$, were adequate for some nutrients (B-group vitamins, vitamin C, P, Fe, Zn, folate and vitamin A retinol equivalents), but limiting for $\mathrm{Mg}, \mathrm{K}, \mathrm{Ca}$, fibre and vitamin $\mathrm{E} \alpha$-tocopherol. Na density was unacceptably high (Fig. 1). Levels of iodine, folate dietary equivalents and $\mathrm{Fe}$ were also lower than the adjusted RDI per $1000 \mathrm{~kJ}$ (Fig. 1). A similar pattern was observed for individual stores (Table 4).

Main food sources of each nutrient reflect both the amount of food purchased and the level of nutrient found in the food ${ }^{(14)}$. Across the six stores, eighteen food types were major contributors to macro- and micronutrients (Tables 5 and 6). Due to both volume purchased and fortification, bread (mainly as white bread) was a major source of many nutrients. Fresh vegetables and fruit were either major or moderate sources of $\beta$-carotene, $\mathrm{Mg}$, vitamin $\mathrm{C}$ and folate in all stores. Beef and/or processed meat were major protein and $\mathrm{Zn}$ sources in all stores, except Store 6. Processed meat (mainly as canned meat) was a moderate source of saturated fat in all stores. For all stores, milk was a major or moderate source of nearly all nutrients. In addition to milk, margarine was a major source of total fat in all stores and a moderate source of saturated fat, except for Store 2 where butter was a moderate source. Bread, savoury sauces, processed meats and baking powder (used daily for making 'damper' - a home-made bread product often cooked on an open fire) were either major or moderate sources of $\mathrm{Na}$. Table sugar and sugar-sweetened drinks (cordials, fruit drinks and soft drinks) combined contributed $62 \cdot 0$ (SD 7.8) \% of total sugar availability.

\section{Discussion}

The present research has shown that point-of-sale data can be used to assess the dietary quality of food sales in remote community stores. It can provide valuable data on nutritional composition of food purchases, volume sold and expenditure patterns.

In the six study stores, despite some inter-community differences and variation in contribution of energy to overall community energy requirements, there were notable consistencies across communities in expenditure patterns, nutrient profile and nutrient sources: (i) high sales of refined carbohydrates (mostly bread and added sugar) that were also major sources of energy; (ii) high sales of added sugars (mostly table sugar and sugarsweetened beverages) that were also major sources of total sugar; (iii) low sales of fruit and vegetables; (iv) few major sources of $\mathrm{Na}$; and (v) several limiting nutrients, to a large extent explained by relatively low sales of wholegrain cereals and fruit and vegetables. 
Table 2 Percentage contributions of food groups to total food expenditure by store: six stores in remote Aboriginal Australia, Remote Indigenous Stores and Takeaway (RIST) project, July-September 2006

\begin{tabular}{|c|c|c|c|c|c|c|c|c|}
\hline \multirow[b]{2}{*}{ Food group } & \multicolumn{6}{|c|}{ Store } & \multirow[b]{2}{*}{ All stores combined } & \multirow[b]{2}{*}{ SD } \\
\hline & 1 & 2 & 3 & 4 & 5 & 6 & & \\
\hline Additives \& cooking ingredients & 0.4 & $0 \cdot 3$ & 0.01 & $0 \cdot 1$ & $0 \cdot 1$ & $0 \cdot 2$ & 0.2 & $0 \cdot 1$ \\
\hline Artificial sweeteners & - & 0.03 & 0.05 & 0.03 & 0.01 & 0.04 & 0.0 & \\
\hline Beverages* & $23 \cdot 0$ & $21 \cdot 0$ & $15 \cdot 9$ & $21 \cdot 5$ & $22 \cdot 1$ & $19 \cdot 2$ & $20 \cdot 5$ & $2 \cdot 6$ \\
\hline Cereals \& cereal productst & $12 \cdot 0$ & $12 \cdot 0$ & $17 \cdot 2$ & $14 \cdot 4$ & $14 \cdot 4$ & $15 \cdot 8$ & $14 \cdot 3$ & $2 \cdot 1$ \\
\hline Eggs \& egg products & $2 \cdot 2$ & $1 \cdot 7$ & $2 \cdot 1$ & 1.9 & 1.5 & $2 \cdot 8$ & $2 \cdot 0$ & 0.5 \\
\hline Fast foods \& takeaway foodsł & $8 \cdot 9$ & $6 \cdot 6$ & $2 \cdot 7$ & $6 \cdot 0$ & $11 \cdot 4$ & $12 \cdot 4$ & $8 \cdot 0$ & $3 \cdot 6$ \\
\hline Fats \& oils & $1 \cdot 6$ & $2 \cdot 8$ & $2 \cdot 7$ & $1 \cdot 2$ & $1 \cdot 1$ & $1 \cdot 5$ & $1 \cdot 8$ & $0 \cdot 7$ \\
\hline Fish \& fish products & $1 \cdot 7$ & 0.9 & $1 \cdot 4$ & $1 \cdot 9$ & $0 \cdot 8$ & $2 \cdot 9$ & $1 \cdot 6$ & $0 \cdot 8$ \\
\hline Fruit§ & $3 \cdot 5$ & $5 \cdot 2$ & 1.5 & $3 \cdot 6$ & $9 \cdot 2$ & $2 \cdot 2$ & $4 \cdot 2$ & $2 \cdot 8$ \\
\hline Infant formulae \& foods & $0 \cdot 8$ & $1 \cdot 5$ & 0.9 & $0 \cdot 9$ & $0 \cdot 1$ & 0.9 & 0.9 & $0 \cdot 4$ \\
\hline Meat, meat products, poultry \& game\|l & $17 \cdot 5$ & $18 \cdot 7$ & $15 \cdot 8$ & $20 \cdot 1$ & $20 \cdot 8$ & $18 \cdot 0$ & $18 \cdot 5$ & $1 \cdot 8$ \\
\hline Milk \& milk products & $10 \cdot 7$ & $10 \cdot 3$ & $17 \cdot 7$ & $12 \cdot 5$ & $5 \cdot 1$ & $7 \cdot 2$ & $10 \cdot 6$ & $4 \cdot 4$ \\
\hline Miscellaneous foods & 0.5 & $0 \cdot 7$ & $1 \cdot 1$ & $0 \cdot 2$ & $0 \cdot 2$ & $0 \cdot 4$ & 0.5 & $0 \cdot 3$ \\
\hline Sauces, pickles, soups, snacks & $3 \cdot 4$ & $3 \cdot 5$ & $4 \cdot 9$ & 1.7 & $6 \cdot 6$ & $4 \cdot 5$ & $4 \cdot 1$ & $1 \cdot 7$ \\
\hline Seeds \& nuts & 0.5 & 0.3 & $0 \cdot 3$ & $0 \cdot 3$ & $0 \cdot 2$ & $0 \cdot 2$ & 0.3 & $0 \cdot 1$ \\
\hline Sugar preserves \& confectionery & $6 \cdot 2$ & $7 \cdot 3$ & $6 \cdot 9$ & $7 \cdot 1$ & 4.5 & $6 \cdot 9$ & $6 \cdot 4$ & $1 \cdot 1$ \\
\hline Vegetable \& vegetable dishes $\S$,** & $7 \cdot 0$ & $7 \cdot 5$ & $8 \cdot 9$ & $7 \cdot 2$ & 1.9 & $4 \cdot 8$ & $6 \cdot 2$ & $2 \cdot 5$ \\
\hline
\end{tabular}

*Beverages - teas, coffees, dry beverage flavourings, fruit drinks, cordials, flavoured drink bases, soft drinks, fruit and vegetable juices and juice drinks (milk drinks are in the milk \& milk products category).

tFlours, cakes, biscuits, bread, grains and starches, breakfast cereals, buns, scones, cereal-based bread equivalents, batters and pastries.

‡Savoury pastry products, pizza, sandwiches, other products where cereal is major ingredient.

$\S$ For Store 5, the percentage contribution of fruit to total food expenditure is an overestimate as fruit and vegetable sales were not individually itemised in the point-of-sale system but entered as fruit and vegetables. Fruit and vegetable sales were categorised as 'Fruit', but assigned a composite nutrient composition. IBeef, lamb, pork, veal, game, poultry, offal, battered and crumbed products, sausages and frankfurters, other processed meats.

- Herbs and spices, vinegars, salad dressings, yeast, yeast vegetable extracts, essences.

${ }^{*}$ Includes all potato and potato products except potato crisps.

Table 3 Percentage contributions of macronutrients to energy availability by store: six stores in remote Aboriginal Australia, Remote Indigenous Stores and Takeaway (RIST) project, July-September 2006. Comparisons with other studies and nutrient requirements

\begin{tabular}{|c|c|c|c|c|c|}
\hline & Protein & Fat & Carbohydrate & Total sugars & Total saturated fat \\
\hline Store 1 & $12 \cdot 9$ & $30 \cdot 5$ & $56 \cdot 0$ & $26 \cdot 6$ & $12 \cdot 3$ \\
\hline Store 2 & $12 \cdot 6$ & $33 \cdot 4$ & $53 \cdot 8$ & $32 \cdot 4$ & $13 \cdot 0$ \\
\hline Store 3 & $13 \cdot 4$ & $36 \cdot 3$ & $49 \cdot 9$ & $26 \cdot 6$ & $14 \cdot 4$ \\
\hline Store 4 & $13 \cdot 5$ & $27 \cdot 7$ & $58 \cdot 8$ & $36 \cdot 0$ & $11 \cdot 0$ \\
\hline Store 5 & $15 \cdot 7$ & $29 \cdot 3$ & $54 \cdot 2$ & $26 \cdot 1$ & $11 \cdot 6$ \\
\hline Store 6 & $13 \cdot 0$ & $33 \cdot 7$ & $53 \cdot 5$ & $25 \cdot 4$ & $12 \cdot 3$ \\
\hline Mean & $13 \cdot 5$ & $31 \cdot 8$ & $54 \cdot 4$ & $28 \cdot 9$ & $12 \cdot 4$ \\
\hline $\mathrm{SD}$ & $1 \cdot 1$ & $3 \cdot 2$ & 3.0 & $4 \cdot 3$ & $1 \cdot 2$ \\
\hline NT communities, mean $1986 / 1987^{(12)}$ & $11 \cdot 0$ & $35 \cdot 5$ & $56 \cdot 8$ & $32 \cdot 6$ & NA \\
\hline Wider Australia, NNS*, $1995^{(15,16)}$ & $16 \cdot 1$ & $33 \cdot 8$ & $47 \cdot 4$ & $22 \cdot 1$ & $13 \cdot 6$ \\
\hline Acceptable Macronutrient Distribution Range ${ }^{(13)}$ & $15-25$ & $20-35$ & $45-65$ & - & $\leq 10$ \\
\hline
\end{tabular}

NNS, National Nutrition Survey; NA, not available.

*Macronutrients to energy for wider Australia also includes a contribution from alcohol of $3 \cdot 2 \%$.

In many respects this reported food purchasing pattern and macronutrient profile is similar to that reported over two decades earlier by Lee et al. in six remote Northern Territory stores ${ }^{(12)}$ : high relative sales of sugarsweetened soft drinks, white bread and table sugar, and low fruit and vegetable sales, and is consistent with that reported for economically marginalised groups in Australia and other affluent Western societies ${ }^{(17,18)}$. In Australia, the most disadvantaged population group is paying more than $40 \%$ more for food than the urban population $^{(19)}$; and high-energy, nutrient-poor foods such as refined cereals, fats and added sugar foods are the cheapest source of energy ${ }^{(20)}$.
Modest improvements in community-level dietary quality and corresponding changes in serum biochemical markers in remote Indigenous Australia have been achieved by targeting increased consumption of specific foods and food groups through structural and community mobilisation strategies ${ }^{(5,6)}$. Subsequent community-based interventions in Australia and store-based interventions overseas ${ }^{(21)}$ have also targeted similar foods and reported modest but positive shifts in the sales of these foods in relation to intervention effect $^{(22-24)}$. Most of these studies have used store invoice or point-of-sale data to measure intervention effect and have targeted specific foods or food groups rather than nutrients. The similarities in patterns of food expenditure, nutrient 


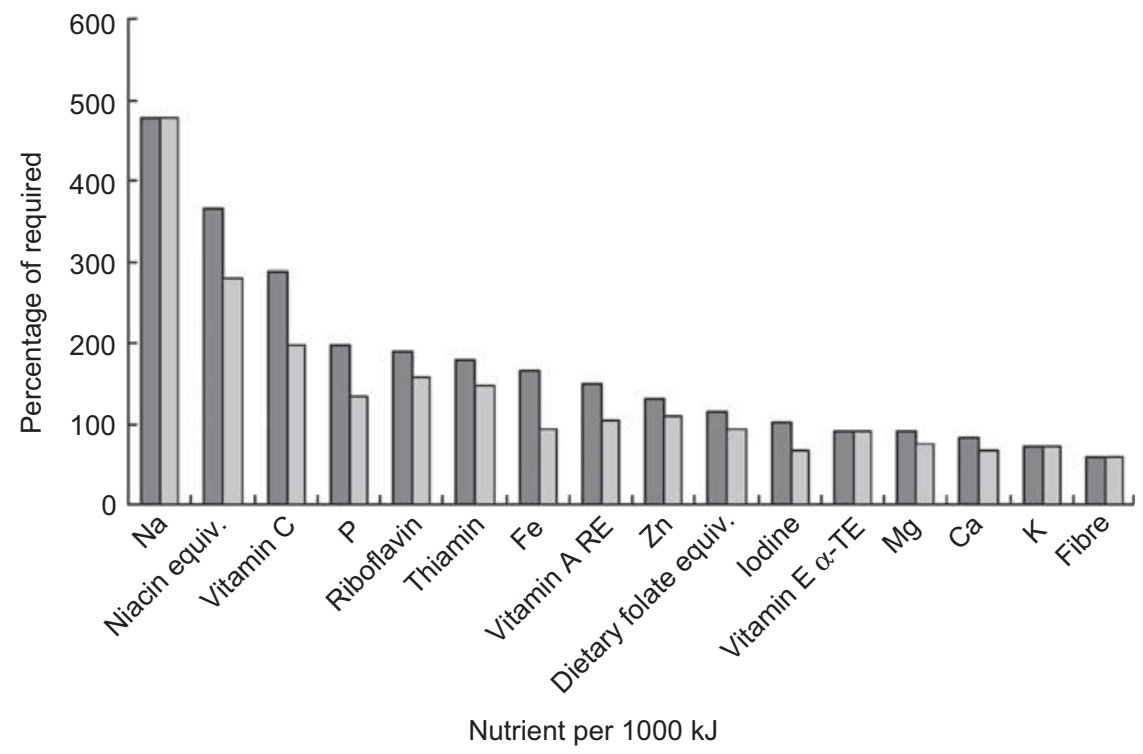

Fig. 1 Nutrient per $1000 \mathrm{~kJ}$ as a percentage of required, based on population-adjusted Estimated Average Requirement (\%EAR, $\square$ ) and Recommended Dietary Intake (\%RDI, $\square$ ), obtained from point-of-sale data from six stores in remote Aboriginal Australia, Remote Indigenous Stores and Takeaway (RIST) project, July-September 2006 (equiv., equivalents; RE, retinol equivalents; $\alpha$-TE, $\alpha$-tocopherol equivalents)

Table 4 Nutrients per $1000 \mathrm{~kJ}$ by store: six stores in remote Aboriginal Australia, Remote Indigenous Stores and Takeaway (RIST) project, July-September 2006. Comparison with wider Australia

\begin{tabular}{|c|c|c|c|c|c|c|c|c|c|}
\hline \multirow[b]{2}{*}{ Nutrient per $1000 \mathrm{~kJ}$} & \multicolumn{6}{|c|}{ Store } & \multirow{2}{*}{$\begin{array}{l}\text { All stores } \\
\text { combined }\end{array}$} & \multirow[b]{2}{*}{ SD } & \multirow{2}{*}{$\begin{array}{l}\text { Wider Australia } \\
\text { NNS (1995) }\end{array}$} \\
\hline & 1 & 2 & 3 & 4 & 5 & 6 & & & \\
\hline Fibre (g) & $1 \cdot 5$ & 1.5 & $1 \cdot 7$ & $1 \cdot 4$ & $1 \cdot 8$ & $1 \cdot 8$ & $1 \cdot 6$ & 0.2 & NA \\
\hline Protein $(\mathrm{g})$ & $7 \cdot 7$ & $7 \cdot 5$ & $8 \cdot 0$ & $8 \cdot 1$ & $9 \cdot 4$ & $7 \cdot 8$ & $8 \cdot 0$ & 0.7 & $9 \cdot 6$ \\
\hline lodine $(\mu \mathrm{g})$ & $11 \cdot 5$ & $11 \cdot 9$ & $11 \cdot 8$ & $9 \cdot 4$ & $7 \cdot 5$ & $8 \cdot 3$ & $10 \cdot 1$ & 1.9 & NA \\
\hline $\mathrm{K}(\mathrm{mg})$ & $236 \cdot 0$ & $254 \cdot 3$ & $247 \cdot 3$ & $222 \cdot 5$ & $240 \cdot 7$ & $221 \cdot 4$ & $237 \cdot 0$ & $13 \cdot 2$ & $345 \cdot 5$ \\
\hline $\mathrm{Fe}(\mathrm{mq})$ & $1 \cdot 1$ & 1.0 & $1 \cdot 1$ & 1.0 & $1 \cdot 3$ & 1.6 & $1 \cdot 2$ & 0.2 & 1.5 \\
\hline $\mathrm{Ca}(\mathrm{mg})$ & $67 \cdot 6$ & $73 \cdot 8$ & $82 \cdot 3$ & $74 \cdot 1$ & $64 \cdot 2$ & $64 \cdot 2$ & $71 \cdot 0$ & $7 \cdot 1$ & 93.6 \\
\hline$P(\mathrm{mg})$ & $135 \cdot 0$ & $142 \cdot 3$ & $144 \cdot 3$ & $130 \cdot 5$ & $134 \cdot 4$ & $125 \cdot 0$ & $135 \cdot 3$ & $7 \cdot 2$ & $162 \cdot 2$ \\
\hline $\mathrm{Mg}(\mathrm{mg})$ & 23.5 & 22.9 & 24.9 & $22 \cdot 6$ & $26 \cdot 1$ & $24 \cdot 1$ & $24 \cdot 0$ & $1 \cdot 3$ & $34 \cdot 6$ \\
\hline $\mathrm{Zn}(\mathrm{mg})$ & $1 \cdot 0$ & $1 \cdot 1$ & $1 \cdot 0$ & $1 \cdot 0$ & $1 \cdot 2$ & $1 \cdot 0$ & $1 \cdot 1$ & $0 \cdot 1$ & $1 \cdot 3$ \\
\hline Thiamin $(\mathrm{mg})$ & 0.13 & 0.14 & 0.18 & $0 \cdot 15$ & $0 \cdot 18$ & $0 \cdot 18$ & $0 \cdot 16$ & 0.0 & $0 \cdot 18$ \\
\hline Riboflavin (mg) & 0.17 & 0.20 & 0.21 & $0 \cdot 18$ & $0 \cdot 15$ & $0 \cdot 16$ & $0 \cdot 18$ & 0.0 & 0.23 \\
\hline Niacin equiv. (ma) & $3 \cdot 8$ & 3.6 & $4 \cdot 3$ & 3.8 & $4 \cdot 7$ & $4 \cdot 2$ & $4 \cdot 1$ & 0.4 & $4 \cdot 4$ \\
\hline Dietary folate equiv. $(\mu \mathrm{g})$ & $28 \cdot 5$ & $36 \cdot 6$ & $37 \cdot 1$ & $34 \cdot 4$ & $34 \cdot 3$ & $36 \cdot 3$ & $34 \cdot 5$ & $3 \cdot 2$ & $28 \cdot 2$ \\
\hline Vitamin $\mathrm{C}(\mathrm{mq})$ & 9.9 & $14 \cdot 7$ & $6 \cdot 3$ & $10 \cdot 6$ & 7.7 & 6.5 & $9 \cdot 3$ & 3.2 & $13 \cdot 4$ \\
\hline $\mathrm{Na}(\mathrm{mg})$ & $360 \cdot 6$ & $301 \cdot 4$ & $345 \cdot 3$ & $275 \cdot 1$ & $343 \cdot 1$ & $352 \cdot 0$ & $329 \cdot 6$ & 33.6 & NA \\
\hline Vitamin E $\alpha$-TE $(\mathrm{mg})$ & 0.8 & $1 \cdot 0$ & 0.8 & 0.6 & 0.7 & 0.8 & 0.8 & 0.1 & NA \\
\hline Vitamin A RE $(\mu \mathrm{q})$ & $71 \cdot 1$ & $80 \cdot 0$ & $93 \cdot 3$ & $69 \cdot 3$ & $84 \cdot 2$ & $64 \cdot 5$ & $77 \cdot 1$ & $10 \cdot 7$ & $124 \cdot 3$ \\
\hline$\beta$-Carotene $(\mu \mathrm{q})$ & $171 \cdot 4$ & $176 \cdot 1$ & $179 \cdot 9$ & $135 \cdot 1$ & $260 \cdot 4$ & $130 \cdot 9$ & $175 \cdot 6$ & $46 \cdot 6$ & NA \\
\hline
\end{tabular}

NNS, National Nutrition Survey; equiv., equivalents; $\alpha$-TE, $\alpha$-tocopherol equivalents; RE, retinol equivalents; NA, not available.

quality and sources of key nutrients shown in the present study suggest potential in the use of remote community store point-of-sale data to: (i) provide an estimate of population-level dietary intake and (ii) monitor trends in dietary intake across communities using key indicator foods; thus providing relatively real-time information to inform strategy and policy development for nutrition improvement in remote Aboriginal communities. Monitoring indicator foods that reflect key nutrients of concern alleviates the need for resource-intensive nutritional analysis. However, ensuring the continued relevance of indicator foods as new issues emerge or as people's food choices diversify would require periodic nutritional analysis of point-of-sale data or checking against other sources of dietary information (which to date have not been available).

The use of point-of-sale data as an estimate of population-level dietary intake depends on the contribution of the store to the overall population-level diet. In urban settings in the UK and New Zealand, supermarket sales data have been shown to be a valid source of information on household food and nutrient availability where supermarket foods contribute most to diet ${ }^{(7,25)}$. Fat and 
energy intakes of households that spend $60 \%$ or more of their food money at supermarkets have reliably been estimated using sales data ${ }^{(25)}$. Individual nutrient intake has been estimated using household supermarket sales data $^{(26)}$ and an association between household obesity and higher-fat food purchasing has also been shown ${ }^{(27)}$. Further, a study in Finland reported similarity between sales of specific food products and reported dietary intake $^{(28)}$. In the 1980 s in remote Australian communities, store invoice data assessed over a 3-month period were shown to provide a reliable estimate of community-level dietary intake as the store was the primary food source ${ }^{(4)}$. Similarly, point-of-sale data are likely to provide a strong estimate of population-level dietary quality in remote Australian communities, as the store is still the primary food source in most communities; distances between communities and neighbouring communities or towns are generally greater than $100 \mathrm{~km}$; competing food businesses are uncommon; and food services such as aged-care programmes and school lunch programmes that are in operation in most communities service a small proportion of the total population ${ }^{(2)}$. The contribution of locally procured or produced food to overall diet is thought to be minimal in remote communities ${ }^{(4)}$; however, this has not been comprehensively examined.

There are a number of inherent limitations in using point-of-sale data to assess dietary quality of food sales that need to be considered in view of these findings. First, food sales provide an estimate of food and nutrient availability, not actual intake, as information on the volume sold and nutrient content of store foods does not always account for preparation or cooking methods, nor does it account for wastage after purchasing. Comparisons of nutrient availability with nutrient requirements may therefore be overestimated. Second, errors at the point of sale or poor maintenance of a point-of-sale system can impact on the quality of food sales data reported. For example, food items that do not have a corresponding universal product identifier (barcode) and cannot be scanned at the point of sale may be incorrectly entered into the point-of-sale system ${ }^{(7)}$. This generally applies to only a small number of products as it is in the best interest of a food retail business to account for all products and ensure correct pricing. Items can also be entered into the point-of-sale system without a corresponding identifiable product description. This occurred for a minimal number of items in the present study and was rectified through identifying the product with the store manager. Items without a universal product identifier may also be given a common product code, such as occurred for fruit and vegetables in Store 5. Lastly, the weight of some food items may not be shown with the product description and must therefore be derived by other means, such as through searching a product weight online or actual weighing of the food item. Our experience in using point-of-sale data is that ongoing use of data and reporting data issues to store managers assist in improving 
Table 6 Food items contributing $\geq 10 \%$ to selected micronutrients for all stores, by order of importance: six stores in remote Aboriginal Australia, Remote Indigenous Stores and Takeaway (RIST) project, July-September 2006

\begin{tabular}{|c|c|c|c|c|c|c|}
\hline Micronutrient & Store 1 & Store 2 & Store 3 & Store 4 & Store 5 & Store 6 \\
\hline $\mathrm{Fe}$ & $\begin{array}{l}\text { Beef } 11 \cdot 4 \text {, bread } 11 \cdot 2, \\
\text { ready-to-eat breakfast } \\
\text { cereal } 10 \cdot 8\end{array}$ & $\begin{array}{l}\text { Ready-to-eat breakfast } \\
\text { cereal } 15 \cdot 2 \text {, beef } 11 \cdot 7\end{array}$ & $\begin{array}{c}\text { Bread } 20 \cdot 8 \text {, ready-to-eat } \\
\text { breakfast cereal } 15 \cdot 8\end{array}$ & $\begin{array}{c}\text { Bread } 16 \cdot 8 \text {, ready-to-eat } \\
\text { breakfast cereal } 13 \cdot 9\end{array}$ & $\begin{array}{l}\text { Bread } 22 \cdot 9 \text {, beef } 16 \cdot 9, \\
\text { ready-to-eat breakfast } \\
\text { cereal } 10 \cdot 1\end{array}$ & $\begin{array}{l}\text { Bread } 29 \cdot 5, \text { flours } 20 \cdot 0, \\
\text { ready-to-eat breakfast } \\
\text { cereal } 10 \cdot 1\end{array}$ \\
\hline $\mathrm{Ca}$ & $\begin{array}{l}\text { Milk } 37 \cdot 2 \text {, baking } \\
\text { powder } 11 \cdot 1\end{array}$ & Milk $49 \cdot 7$ & Milk $46 \cdot 8$, bread 13.5 & Milk $47 \cdot 6$, bread $13 \cdot 5$ & Milk $32 \cdot 3$, bread $19 \cdot 3$ & Milk $39 \cdot 7$, bread $19 \cdot 2$ \\
\hline $\begin{array}{l}\text { Dietary folate } \\
\text { equiv. }\end{array}$ & $\begin{array}{l}\text { Bread } 13 \cdot 4 \text {, ready-to-eat } \\
\text { breakfast cereal } 11 \cdot 8 \text {, tea/ } \\
\text { coffee/powder } 11 \cdot 1\end{array}$ & $\begin{array}{l}\text { Tea/coffee/powder } 23 \cdot 3, \\
\text { ready-to-eat breakfast } \\
\text { cereal } 12 \cdot 3 \text {, milk } \\
10 \cdot 4, \text { yeast vegetable } \\
\text { extract } 10 \cdot 3\end{array}$ & $\begin{array}{l}\text { Bread } 19 \cdot 0, \text { ready-to-eat } \\
\text { breakfast cereal } 13 \cdot 6, \\
\text { yeast vegetable extract } \\
13 \cdot 0, \text { milk } 11 \cdot 7, \text { tea/coffee/ } \\
\text { powder } 11 \cdot 2\end{array}$ & $\begin{array}{l}\text { Tea/coffee/powder } 26 \cdot 5 \text {, } \\
\text { bread } 16 \cdot 9, \text { ready-to-eat } \\
\text { breakfast cereal } 12 \cdot 1\end{array}$ & $\begin{array}{l}\text { Bread } 25 \cdot 9, \text { tea/coffee/ } \\
\text { powder } 18 \cdot 2 \text {, other fruit } \\
10 \cdot 2 \text {, ready-to-eat } \\
\text { breakfast cereal } 10 \cdot 2\end{array}$ & $\begin{array}{l}\text { Tea/coffee/powder } 31 \cdot 1 \text {, } \\
\text { bread } 16 \cdot 6, \text { ready-to-eat } \\
\text { breakfast cereal } 12 \cdot 4\end{array}$ \\
\hline $\mathrm{Zn}$ & $\begin{array}{l}\text { Beef } 24 \cdot 8 \text {, other processed } \\
\text { meats } 10 \cdot 0 \text { (canned meat) }\end{array}$ & Beef $26 \cdot 4$, milk $12 \cdot 3$ & $\begin{array}{l}\text { Other processed meats } 14 \cdot 1 \text {, } \\
\text { milk } 14 \cdot 0, \text { bread } 13 \cdot 7\end{array}$ & $\begin{array}{l}\text { Beef } 17 \cdot 0, \text { bread } 12 \cdot 0 \\
\text { milk } 11 \cdot 7\end{array}$ & Beef $37 \cdot 1$, bread $13 \cdot 6$ & Bread 14.6 \\
\hline Thiamin & $\begin{array}{l}\text { Bread } 23 \cdot 7, \text { flours } 18 \cdot 9, \\
\text { ready-to-eat breakfast } \\
\text { cereal } 15 \cdot 8\end{array}$ & $\begin{array}{l}\text { Ready-to-eat breakfast } \\
\text { cereal } 21 \cdot 2, \text { flours } 20 \cdot 4 \text {, } \\
\text { bread } 15 \cdot 8\end{array}$ & $\begin{array}{c}\text { Bread } 33 \cdot 1 \text {, ready-to-eat } \\
\text { breakfast cereal } 16 \cdot 9\end{array}$ & $\begin{array}{l}\text { Bread } 30 \cdot 9 \text {, ready-to-eat } \\
\text { breakfast cereal } 17 \cdot 8, \\
\text { flour } 15 \cdot 2\end{array}$ & $\begin{array}{l}\text { Bread } 40 \cdot 8 \text {, ready-to-eat } \\
\text { breakfast cereal } 14 \cdot 0, \\
\text { flours } 11 \cdot 5\end{array}$ & $\begin{array}{l}\text { Bread } 34 \cdot 8 \text {, ready-to-eat } \\
\text { breakfast cereal } 18 \cdot 2, \\
\text { flours } 15 \cdot 1\end{array}$ \\
\hline Riboflavin & $\begin{array}{l}\text { Milk } 31 \cdot 0 \text {, ready-to-eat } \\
\text { breakfast cereal } 10 \cdot 1\end{array}$ & $\begin{array}{l}\text { Milk } 38 \cdot 4 \text {, ready-to-eat } \\
\text { breakfast cereal } 11 \cdot 0\end{array}$ & $\begin{array}{l}\text { Milk } 37 \cdot 3 \text {, ready-to-eat } \\
\text { breakfast cereal } 12 \cdot 0\end{array}$ & $\begin{array}{l}\text { Milk } 36 \cdot 3 \text {, ready-to-eat } \\
\text { breakfast cereal } 11 \cdot 1\end{array}$ & $\begin{array}{l}\text { Milk } 24 \cdot 2 \text {, ready-to-eat } \\
\text { breakfast cereal } 10 \cdot 9\end{array}$ & $\begin{array}{l}\text { Milk } 28 \cdot 0 \text {, ready-to-eat } \\
\text { breakfast cereal } 13 \cdot 8\end{array}$ \\
\hline Niacin equiv. & Bread $17 \cdot 6$, beef $14 \cdot 7$ & $\begin{array}{l}\text { Beef } 17 \cdot 5 \text {, bread } 13 \cdot 2, \\
\text { milk } 12 \cdot 1\end{array}$ & $\begin{array}{l}\text { Bread } 28 \cdot 8 \text {, other processed } \\
\text { meats } 12 \cdot 1, \text { milk } 11 \cdot 2\end{array}$ & Bread $26 \cdot 1$, beef $14 \cdot 8$ & $\begin{array}{l}\text { Bread } 34 \cdot 1 \text {, beef } 20 \cdot 6 \text {, } \\
\text { milk } 11 \cdot 6\end{array}$ & Bread 31.0 \\
\hline $\mathrm{Mg}$ & $\begin{array}{l}\text { Grains \& starches } 11 \cdot 4 \text {, milk } \\
10 \cdot 8, \text { bread } 10 \cdot 4\end{array}$ & Milk $16 \cdot 1$, vegetables $10 \cdot 7$ & $\begin{array}{l}\text { Bread } 19 \cdot 1, \text { milk } 15 \cdot 7 \\
\text { vegetables } 11 \cdot 9\end{array}$ & Bread $16 \cdot 1$, milk $15 \cdot 5$ & Bread $23 \cdot 6$, beef $11 \cdot 1$ & Bread $22 \cdot 5$, milk $10 \cdot 4$ \\
\hline Vitamin C & $\begin{array}{l}\text { Fruit drink/cordial/soft drink } \\
33 \cdot 2 \text {, vegetables } 28 \cdot 8, \text { fruit } \\
\& \text { vegetable juice } 18 \cdot 0\end{array}$ & $\begin{array}{l}\text { Fruit drink/cordial/soft } \\
\text { drink } 36 \cdot 3, \text { fruit } \& \\
\text { vegetable juice } 24 \cdot 6 \text {, } \\
\text { vegetables } 22 \cdot 1\end{array}$ & $\begin{array}{c}\text { Vegetables } 50 \cdot 2 \text {, fruit \& } \\
\text { vegetable juice } 25 \cdot 8\end{array}$ & $\begin{array}{l}\text { Fruit drink/cordial/soft drink } \\
45 \cdot 3 \text {, fruit \& vegetable } \\
\text { juice } 25 \cdot 2 \text {, vegetables } \\
10 \cdot 9\end{array}$ & $\begin{array}{l}\text { Fruit \& vegetable juice } 44 \cdot 7, \\
\text { other fruit } 40 \cdot 1\end{array}$ & $\begin{array}{l}\text { Fruit \& vegetable juice } \\
35 \cdot 5, \text { vegetables } 28 \cdot 7 \\
\text { fruit drink/cordial/soft } \\
\text { drink } 10 \cdot 1\end{array}$ \\
\hline $\mathrm{Na}$ & $\begin{array}{l}\text { Baking powder } 26 \cdot 2 \text {, savoury } \\
\text { sauces } 14 \cdot 1 \text {, bread } 10 \cdot 2\end{array}$ & $\begin{array}{l}\text { Baking powder } 22 \cdot 3 \text {, other } \\
\text { processed meats } 11 \cdot 6\end{array}$ & $\begin{array}{l}\text { Other processed meats } 22 \cdot 1 \text {, } \\
\text { bread } 20 \cdot 0\end{array}$ & $\begin{array}{l}\text { Bread } 22 \cdot 9 \text {, baking powder } \\
12 \cdot 4 \text {, other processed } \\
\text { meats } 12 \cdot 1\end{array}$ & $\begin{array}{l}\text { Bread } 25 \cdot 0 \text {, baking } \\
\text { powder } 10 \cdot 6\end{array}$ & $\begin{array}{l}\text { Bread } 20 \cdot 1 \text {, baking } \\
\text { powder } 16 \cdot 6\end{array}$ \\
\hline Vitamin A RE & $\begin{array}{l}\text { Vegetables } 23 \cdot 9, \text { milk } 17 \cdot 6, \\
\text { margarines } 16.9\end{array}$ & $\begin{array}{l}\text { Milk } 23 \cdot 7 \text {, vegetables } 23 \cdot 5 \text {, } \\
\text { margarines } 16 \cdot 3\end{array}$ & $\begin{array}{l}\text { Margarines } 26 \cdot 7 \text {, vegetables } \\
20 \cdot 9 \text {, milk } 19 \cdot 9\end{array}$ & $\begin{array}{l}\text { Milk } 23 \cdot 6 \text {, margarines } \\
18 \cdot 1 \text {, vegetables } 14 \cdot 5\end{array}$ & $\begin{array}{l}\text { Other fruit } 40 \cdot 0^{*} \text {, margarine } \\
23 \cdot 5 \text {, milk } 11 \cdot 4\end{array}$ & $\begin{array}{l}\text { Margarines } 22 \cdot 1 \text {, milk } 18 \cdot 5 \text {, } \\
\text { vegetables } 16 \cdot 9\end{array}$ \\
\hline $\mathrm{K}$ & Vegetables $17 \cdot 3$, milk 14.9 & Milk $20 \cdot 2$, vegetables $19 \cdot 4$ & Vegetables $23 \cdot 3$, milk $22 \cdot 0$ & Milk $21 \cdot 6$, vegetables $11 \cdot 5$ & $\begin{array}{l}\text { Beef } 17 \cdot 0 \text {, milk } 11 \cdot 6 \text {, other } \\
\text { fruit } 11 \cdot 6^{*} \text {, bread } 10 \cdot 8\end{array}$ & $\begin{array}{l}\text { Milk } 15 \cdot 5 \text {, vegetables } 13 \cdot 1 \text {, } \\
\text { bread } 12 \cdot 0\end{array}$ \\
\hline$P$ & Milk $16 \cdot 3$, beef $10 \cdot 5$ & Milk $22 \cdot 7$, flour $14 \cdot 3$ & $\begin{array}{l}\text { Milk } 23 \cdot 4 \text {, processed meat } \\
12 \cdot 1 \text {, bread } 11 \cdot 6\end{array}$ & Milk $22 \cdot 9$, bread $11 \cdot 8$ & $\begin{array}{l}\text { Beef } 18 \cdot 7 \text {, bread } 15 \cdot 4 \text {, milk } \\
13 \cdot 0\end{array}$ & Milk $17 \cdot 2$, bread $15 \cdot 0$ \\
\hline$\beta$-Carotene & $\begin{array}{l}\text { Vegetables } 59 \cdot 3 \text {, other } \\
\text { fruit } 11 \cdot 7\end{array}$ & Vegetables $64 \cdot 0$ & Vegetables 64.9 & Vegetables $44 \cdot 6$ & Other fruit $77 \cdot 7^{\star}$ & $\begin{array}{l}\text { Vegetables } 49 \cdot 9 \text {, other } \\
\text { products where cereal } \\
\text { major ingredient } 14 \cdot 0\end{array}$ \\
\hline Vitamin E $\alpha$-TE & $\begin{array}{l}\text { Vegetable oils } 30 \cdot 7 \\
\text { margarines } 14 \cdot 7\end{array}$ & Vegetable oils $45 \cdot 3$ & $\begin{array}{l}\text { Vegetable oils } 33 \cdot 1 \\
\text { margarines } 18.9\end{array}$ & $\begin{array}{l}\text { Vegetable oils } 21 \cdot 6 \text {, } \\
\text { margarines } 12 \cdot 6, \\
\text { eggs } 10 \cdot 3\end{array}$ & $\begin{array}{l}\text { Vegetable oils } 20 \cdot 4 \\
\text { margarines } 16 \cdot 0\end{array}$ & $\begin{array}{l}\text { Vegetable oils } 12 \cdot 0 \\
\text { margarines } 12 \cdot 3\end{array}$ \\
\hline
\end{tabular}

equiv., equivalents; RE, retinol equivalents; $\alpha$-TE, $\alpha$-tocopherol equivalents.

This is likely vegtables, as point-of-sale data on fruit and vegetables for Store 5 were not itemised and vegetables in the other community stores contributed most to $\beta$-carotene. 
the quality of the point-of-sale system. Rigorous data checking is needed, however, to assure data quality.

Caution must be applied in the estimates of communitylevel energy requirements reported in the present study as these are dependent on population size estimates which are known to be problematic for remote Australian communities $^{(4)}$. A strength of our study is the use of nutrient density (nutrient amount per $1000 \mathrm{~kJ}$ ), which is independent of population size and therefore allows comparison across communities ${ }^{(12)}$. A 3-month period was assessed in the present study. A longer study period and a larger sample of community stores would enable a more comprehensive evaluation of food and nutrient patterns across stores and seasonal variation to be assessed. Despite these limitations, the advantages of point-of-sale data as a measure of dietary quality exceed the limitations as traditional means of dietary assessment are notoriously incomplete, expensive and inherently challenging to conduct ${ }^{(29,30)}$. Caution must also be applied in making comparisons with wider Australia as the only dietary data available for the wider Australian population are now dated.

The present study has international relevance. It contributes importantly to methods in the use of point-of-sale data to assess dietary quality of food sales and populationlevel dietary quality. Through the study we developed an automated tool to upload point-of-sale data and assign food items to food groups and corresponding nutrient composition using step-by-step automated procedures. This tool minimises potential coding errors, allows for rigorous, step-by-step point-of-sale data checking and allows for automated and timely reporting of dietary quality. We have applied this methodology to monitor point-of-sale data longitudinally and to evaluate nutrition-related interventions on food sales in multiple stores ${ }^{(31)}$.

\section{Conclusions}

Point-of-sale data offer an objective, cost-efficient and unobtrusive measure of dietary quality of food sales which places no burden on individuals and with few of the limitations associated with individual dietary assessment methods ${ }^{(7,11)}$. Store point-of-sale data in remote Australian communities may provide an estimate of population dietary intake, however this needs further examination. There is great potential for the development of a food and nutrition monitoring system for remote communities based on pointof-sale data in Australia and in similar overseas contexts where the store is the primary food source and where communities are distanced from alternative food sources.

\section{Acknowledgements}

Sources of funding: This work was supported by the National Health and Medical Research Council
(NHMRC; grant numbers 124319 and 320860); an NHMRC Public Health Fellowship (number 545253); and the Remote Indigenous Stores and Takeaway (RIST) project. Conflicts of interest: There are no conflicts of interest. Authors' contributions: J.B. designed the study, analysed the data and wrote the manuscript. R.L. contributed to database design and management, data analysis and the manuscript. K.O. contributed to data analysis and the manuscript. Acknowledgements: Appreciation is extended to the six community stores and respective store managers who participated in the RIST project. Thanks to Professor Ross Bailie (Menzies School of Health Research) and Carrie Turner (Senior Nutritionist, Northern Territory Department of Health) for providing feedback on an early draft of this report. Thanks also to the RIST committee members, particularly Vivienne Hobson, Dympna Leonard, Robyn Bowcock and Patricia Carter who provided feedback at various stages of the project.

\section{References}

1. Vos T, Barker B, Begg S et al. (2009) Burden of disease and injury in Aboriginal and Torres Strait Islander Peoples: the Indigenous health gap. Int J Epidemiol 38, 470-477.

2. Brimblecombe J, Mackerras D, Clifford P et al. (2006) Does the store-turnover method still provide a useful guide to food intakes in Aboriginal communities? Aust N Z J Public Health 30, 444-447.

3. The Parliament of the Commonwealth of Australia, House of Representatives: Aboriginal and Torres Strait Islander Affairs Committee (2009) Everybody's Business: Remote Aboriginal and Torres Strait Islander Community Stores. Canberra: Commonwealth of Australia.

4. Lee AJ, Smith A, Bryce S et al. (1995) Measuring dietary intake in remote Australian Aboriginal communities. Ecol Food Nutr 34, 19-31.

5. Rowley KG, Daniel M, Skinner K et al. (2000) Effectiveness of a community-directed 'healthy lifestyle' program in a remote Australian Aboriginal community. Aust N Z J Public Health 24, 136-144.

6. Lee AJ, Bailey AP, Yarmirr D et al. (1994) Survival tucker: improved diet and health indicators in an Aboriginal community. Aust J Public Health 18, 277-285.

7. Tin Tin S, Ni Mhurchu C \& Bullen C (2007) Supermarket sales data: feasibility and applicability in population food and nutrition monitoring. Nutr Rev 65, 20-30.

8. Australian Bureau of Statistics (2007) 2006 Census Tables. In 2006 Census of Population and Housing. ABS Catalogue no. 2068.0. Canberra: Commonwealth of Australia.

9. Brimblecombe J (2008) Keeping Track of Healthy Foods: Towards Improving the Nutritional Quality of Foods sold in Community Stores in Remote Australia. Darwin, NT: Menzies School of Health Research.

10. Food Standards Australia New Zealand (2007) Food Composition Program NUTTAB 2006. http://www.foodstandards.gov.au/monitoringandsurveillance/nuttab2006/ index.cfm (accessed March 2009).

11. Hamilton S, Ni Mhurchu C \& Priest P (2007) Food and nutrient availability in New Zealand: an analysis of supermarket sales data. Public Health Nutr 10, 1448-1455.

12. Lee AJ, O’Dea K \& Mathews JD (1994) Apparent dietary intake in remote Aboriginal communities. Aust J Public Health 18, 190-197. 
13. Australian Government, Department of Health and Ageing, National Health and Medical Research Council \& Ministry of Health: Manatu Hauora (2006) Nutrient Reference Values for Australia and New Zealand Including Recommended Dietary Intakes. Canberra: Commonwealth of Australia.

14. Australian Bureau of Statistics (2000) Apparent Consumption of Foodstuffs Australia, 1997-98 and 1998-99. ABS Catalogue no. 4306.0. Canberra: Commonwealth of Australia.

15. Australian Bureau of Statistics (1999) National Nutrition Survey: Foods Eaten, Australia, 1995. ABS Catalogue no. 4804.0. Canberra: Commonwealth of Australia.

16. Australian Bureau of Statistics, Department of Health and Aged Care (1998) National Nutrition Survey: Nutrient Intakes and Physical Measurements, Australia, 1995. ABS Catalogue no. 4805.0. Canberra: Commonwealth of Australia.

17. Drewnowski A \& Specter SE (2004) Poverty and obesity: the role of energy density and energy costs. Am J Clin Nutr 79, 6-16.

18. Giskes K, Turrell G, Patterson C et al. (2002) Socioeconomic differences among Australian adults in consumption of fruit and vegetables and intakes of vitamins A, C and folate. J Hum Nutr Diet 15, 375-385.

19. Northern Territory Government, Nutrition and Physical Activity Program (2011) Northern Territory Market Basket Survey 2011. Darwin, NT: DoH, Nutrition and Physical Activity.

20. Brimblecombe JK \& O'Dea K (2009) The role of energy cost in food choices for an Aboriginal population in northern Australia. Med J Aust 190, 549-551.

21. Gittelsohn J, Song HJ, Suratkar S et al. (2010) An urban food store intervention positively affects food-related psychosocial variables and food behaviors. Health Educ Behav 37, 390-402.

22. Rowley KG, Su Q, Cincotta M et al. (2001) Improvements in circulating cholesterol, antioxidants, and homocysteine after dietary intervention in an Australian Aboriginal community. Am J Clin Nutr 74, 442-448.
23. Tyrrell M, Grundy J, Lynch P et al. (2003) Laramba Diabetes Project: an evaluation of a participatory project in a remote Northern Territory community. Health Promot J Aust 14 , $48-53$.

24. Lee AJ, Hobson V \& Katarski L (1996) Review of the nutrition policy of the Arnhem Land Progress Association. Aust N Z J Public Health 20, 538-544.

25. Ransley JK, Donnelly JK, Khara TN et al. (2001) The use of supermarket till receipts to determine the fat and energy intake in a UK population. Public Health Nutr 4, 1279-1286.

26. Eyles H, Jiang Y \& Ni Mhurchu C (2010) Use of household supermarket sales data to estimate nutrient intakes: a comparison with repeat 24-hour dietary recalls. J Am Diet Assoc 110, 106-110.

27. Ransley JK, Donnelly JK, Botham H et al. (2003) Use of supermarket receipts to estimate energy and fat content of food purchased by lean and overweight families. Appetite 41, 141-148.

28. Narhinen M, Berg MA, Nissinen A et al. (1999) Supermarket sales data: a tool for measuring regional differences in dietary habits. Public Health Nutr 2, 277-282.

29. Beaton GH, Milner J, McGuire V et al. (1983) Source of variance in 24-hour dietary recall data: implications for nutrition study design and interpretation. Carbohydrate sources, vitamins, and minerals. Am J Clin Nutr 37, 986-995.

30. Harrison GG (2004) Proceedings of the workshop on foodconsumption surveys in developing countries: methodologic considerations in descriptive food-consumption surveys in developing countries. Food Nutr Bull 25, 415-419.

31. Brimblecombe JK, McDonnell J, Barnes A et al. (2010) Impact of income management on store sales in the Northern Territory. Med J Aust 192, 549-554.

32. Australian Bureau of Statistics (2007) Births, Australia 2006. ABS Catalogue no. 3301.0. Canberra: Australian Bureau of Statistics. 